\title{
Organophosphate Residue in Different Land Use in Mojogedang Karanganyar Central Java Indonesia
}

\author{
Supriyadi ${ }^{1}$, Aditya Dyah Utami ${ }^{1}$, Hery Widijanto ${ }^{1} \&$ Sumani $^{1}$ \\ ${ }^{1}$ Study Program of Agrotechnology, Faculty of Agriculture, University of Sebelas Maret (UNS), Surakarta, \\ Indonesia \\ Correspondence: Supriyadi, Study Program of Agrotechnology, Faculty of Agriculture, University of Sebelas \\ Maret (UNS), Jl. Ir. Sutami 36A Kentingan, Jebres, Surakarta, Indonesia. Tel: 62-081-7948-8860. E-mail: \\ supriyadi_uns@yahoo.com
}

Received: December 1, 2014

Accepted: December 8, 2014 Online Published: April 25, 2015

doi:10.5539/mas.v9n6p87

URL: http://dx.doi.org/10.5539/mas.v9n6p87

\begin{abstract}
The use of inorganic pesticides result in residues of pesticides in the environment. Mojogedang is an area that has implemented a system of organic farming but also there are farmers who apply chemical pesticides. Pesticides are commonly used by farmers in Mojogedang causing residues, such as organophosphate. Organophosphates contains the active ingredient with a relatively long persistence in the environment and dangerous that it needs a study to investigate the organophosphate residues. The aims of this research to study the level of organophosphate residue and their exposure to soil properties in a variety of land uses in Mojogedang (paddy field, dryland, community forest). This study to analize organic- $\mathrm{C}, \mathrm{pH}$, soil texture, total microbia and organophosphate residues including diazinon, parathion, profenofos, ethion, chlorpyrifos, malathion. Data was analized statistically using correlation analysis. Results of this study show that all residue consentration of organophosphate residues active ingredients in organic paddy field soil, inorganic paddy field soil, dryland soil, community forest soil less than maximum residue limits (MRL) 0,05 mg/kg. Residue levels of horticultural dryland with profenofos active ingredient more than MRL $(62,060 \mathrm{mg} / \mathrm{kg})$ while the other active ingredient less than MRL. Soil texture is a soil property which closely correlate with organophosphate residues in the soil (sand fraction $r=-0,601$, dust fraction $r=-0,658$, clay fraction $=-0,509$ ).
\end{abstract}

Keyword: organophosphate, pesticide, residue, soil characteristics

\section{Introduction}

Indonesian population increase on average by $1.49 \%$ every year (Statistic Indonesia, 2014) resulted in increased food needs. Increased food needs are not supported by the availability of productive agricultural land, thus increasing agricultural production is only 1.3\% annually (Simatupang et al., 1995 cit Noordwijk and Hairiah 2006). The lack of availability of food make the government implement a strategy to meet the food needs of the pattern of agricultural intensification. Agricultural intensification requires that farmers use high external input in agricultural land one anorganic pesticide application.

Farmers in Indonesia generally apply pesticides in prevent plant pests to increase agricultural production (Aktar et al., 2009). Based on data from the Directorate of Fertilizers and Pesticides (2012) total pesticide consumption in 2008 amounted to 92048 tonnes, 90050 tonnes in 2009 amounted to 2010 amounted to 92504 tonnes and 100736 tonnes in 2015 is projected to percentage average rate increase of $2.69 \%$ per year. The high use of pesticides also has a negative impact due to the residue left behind, such as exposure to environmental and agricultural products (Fatimah and Nugraha 2007; Bhupander 2011; Bai et al., 2010; Hasan 2006), food products (Bo et al., 2011; Dehghani et al., 2011), the economic losses (Djunaedy, 2009) and human health (Chowdhary et al., 2014; Rustia et al., 2010).

Pesticide residues in the environment are difficult to dispersed. One of inorganic pesticide residues harmful to the environment is organophosphate insecticide which is a class of phosphoric acid esters or acid tiofosfat (Raini 2007) with high persistence and very dangerous (Indratin et al., 2010; Leroy et al., 2010). In Indonesia, 23.9\% of the total $55.42 \%$ insecticide used widely circulated and are organophosphates (Ministry of Health of the Republic of Indonesia in 1998 cit Nurlamba et al., 2010), while the use of organophosphates in the world total $38 \%$ of all insecticides are inorganic (Tabassum et al., 2012). 
Mojogedang is one of the districts in Karanganyar with the majority of the population are farmers (Statistic of Karanganyar, 2013). Mojogedang farmers have largely been implemented organic farming systems but there are still farmers who apply inorganic pesticides. Inorganic pesticides are widely applied to farmers belonging to the organophosphates. The inorganic pesticide application depends on the level of pest attack. The higher pest attacks increase the frequency of spraying which is 6 times each season (3 months) (Sularti and Muhlisin, 2011). This causes the increasing of inorganic pesticide residues and exposure to the environment, especially in the soil.

Mojogedang agricultural land (Statistic of Karanganyar, 2013) was 3135.428 hectares (ha) and there are variations in land use systems include 2024.757 ha of paddy fields, 856.352 ha of drylands, community forest for 254.319 ha. Land use system determines the level of inorganic pesticide application. Based on this background, it is important to do research on exposure to organophosphate residues on various land use in Mojogedang.

\section{Materials and Method}

\subsection{Place and Time ot the Research}

This research was conducted in October 2013 to February 2014 in the District Mojogedang, Karanganyar. Geographically, the area is located at $7^{\circ} 32^{\prime} 10^{\prime \prime}$ South Longitude and $111^{\circ} 00^{\prime} 05^{\prime \prime}$ East Longitude, while the laboratory analysis conducted in the Biology and Soil Biotechnology, Laboratory and Chemistry and Soil Fertility Laboratory of Agricultural Faculty University of Sebelas Maret (UNS) and Research and Integrated Trial Laboratory University of Gajah Mada (UGM).

\subsection{Materials and Equipment}

Materials used includeing land use maps District of Mojogedang, samples of organic paddy field soil, inorganic paddy field soil, dryland soil, community forest soil, horticultural dryland, plastic and chemicals for laboratory analysis. Tools used include soil sampling equipment, scales, sieve $\varnothing 2 \mathrm{~mm}$ and $\varnothing 0,5 \mathrm{~mm}$ and laboratory analytical tools.

\subsection{Research Design and Sampling Techniques}

Explorative descriptive research methods and laboratory analysis with a survey approach. How to determine the location of the study based on Indonesian soil in such a map overlay. Maps used are maps of land use in Mojogedang, Karanganyar. Obtained three types of land use for agriculture, which are paddy fields, drylands, and community forests.

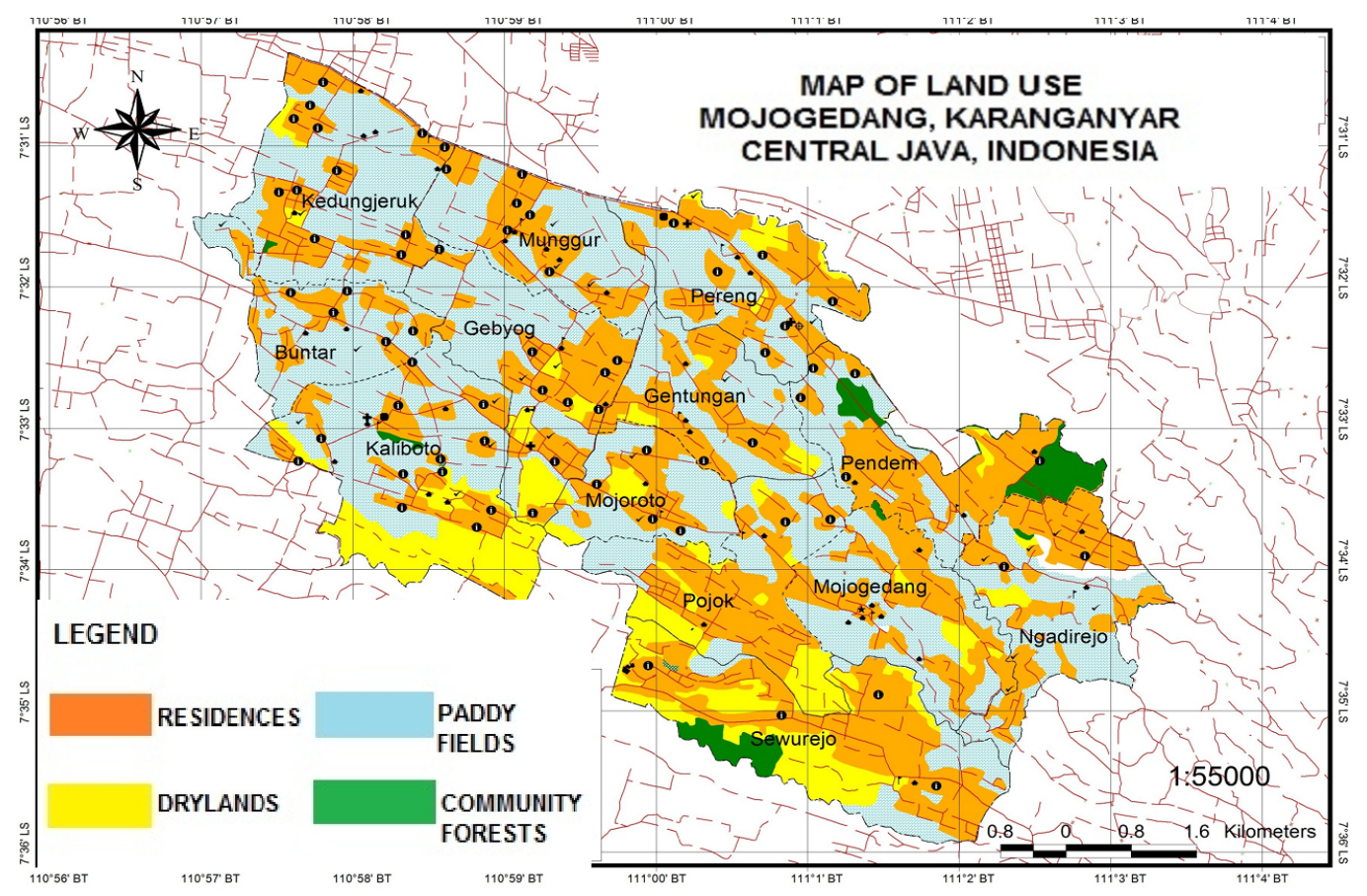

Figure 1. The Land Use Map of the Mojogedang Karanganyar 


\subsection{Types and Sources of Data}

The data used in the form of primary and secondary data. Primary data obtained from laboratory analysis is the analysis organic- $\mathrm{C}, \mathrm{pH}$, soil texture and total microbia. Secondary data, rainfall over the last 10 years (2003-2012) in the District Mojogedang and identity questionnaire containing inorganic and organic farmers, crop cultivation, use of pesticides, pesticide application method, dosage, and frequency of pesticide spraying.

\subsection{Data Analysis}

Data analysis laboratory tested using Minitab 13.0 software with correlation test to determine the relationship between observed variables.

\section{Results and Discussion}

\subsection{General Conditions Research Sites}

The research location in the Pereng, Pendem, and Gentungan Village, Mojogedang, Karanganyar. Geographically, the area is located at $7^{\circ} 32^{\prime} 10^{\prime \prime}$ South Longitude and $111^{\circ} 00^{\prime} 05^{\prime \prime}$ East Longitude. Mojogedang agricultural land area is 3135.428 ha and there are variations in land use systems include 2024.757 ha of paddy fields, $856.352 \mathrm{Ha}$ of drylands and 254.319 ha of community forests (Statistic of Karanganyar, 2013).

The type of soil that dominates the area included in the order Entisols, according to Statistic of Karanganyar (2013). Entisols have a rough texture characteristic with low organic matter is less than 1\% (Munir 1996). The Table 1. below shows the location Entisols fertility research in the organic paddy fields, inorganic paddy fields, dryland soil, horticultural dryland and community forest.

Table 1. The mean soil physical and chemical properties measurement for difference land use

\begin{tabular}{|c|c|c|c|c|c|c|}
\hline \multirow[b]{2}{*}{ Land use } & \multicolumn{3}{|c|}{ Soil Texture } & \multirow[b]{2}{*}{ Scoring *) } & \multirow[b]{2}{*}{$\mathrm{pH} \mathrm{H}_{2} \mathrm{O}$} & \multirow[b]{2}{*}{$\begin{array}{c}\text { Organic-C } \\
(\%)\end{array}$} \\
\hline & $\begin{array}{c}\text { Sand } \\
(\%)\end{array}$ & $\begin{array}{c}\text { Dust } \\
(\%)\end{array}$ & $\begin{array}{l}\text { Clay } \\
(\%)\end{array}$ & & & \\
\hline $\begin{array}{l}\text { Organic paddy } \\
\text { field }\end{array}$ & 67 & 20 & 13 & & 6,3 & 1,14 \\
\hline $\begin{array}{l}\text { Inorganic } \\
\text { paddy field }\end{array}$ & 68 & 28 & 5 & & 6,1 & 0,87 \\
\hline $\begin{array}{l}\text { Horticultural } \\
\text { dryland }\end{array}$ & 64 & 30 & 6 & loamy sand & 5,7 & 1,02 \\
\hline Dryland & 76 & 10 & 14 & & 4,3 & 0,52 \\
\hline $\begin{array}{l}\text { Community } \\
\text { forest }\end{array}$ & 70 & 11 & 19 & & 4,6 & 0,47 \\
\hline
\end{tabular}

There are physical and chemical properties similarities of land in each study site (Table 1). Soil texture is loamy sand any location with an average percentage fraction $>60 \%$ sand, $>10 \%$ of dust and $>5 \%$ clay. Based on Table 1 , the texture of community forest soil is more developed indicated clay a higher percentage than clay on other agricultural land. The number and density of plant root causes of community forest destruction coarse fraction become smoother faster (Arifin 2011). Arifin (2011) also added plant litter decomposition process will produce organic acids that play a role in the breakdown of soil fractions.

The relatively high level of soil acidity $\mathrm{pH}$ range from 4 to 6.5 (Table 1) due to high rainfall in a Mojogedang average of $3861.7 \mathrm{~mm} /$ year. Excessive rainfall resulted in leaching alkaline cations $\mathrm{Ca}^{+}, \mathrm{Mg}^{2+}, \mathrm{K}^{+}$, and $\mathrm{Na}^{+}$are replaced with $\mathrm{H}^{+}$and $\mathrm{Al}^{3+}$ (Munawar, 2011). Organic paddy field and inorganic paddy field $\mathrm{pH}$ close to neutral. Paddy fields which constantly processed and flooded lead-acid leaching of organic acids and inhibit oxidation thus increasing soil pH (Maroeto and Sasongko, 2004).

Inorganic paddy field more acid than organic paddy field (Table 1). This is because the application of chemical fertilizers can acidity the soil (Utami and Handayani, 2003) due to oxidation and hydrolysis of chemical fertilizers, such as nitrogen (N) and phosphorus (P) increase soil acidity (Munawar, 2011). The application of organic fertilizer on inorganic paddy field lead to an increase in soil $\mathrm{pH}$ (Dahlan et al., 2008) due to the decomposition of organic matter will release base cation sand increase organic-C (Sevindrajuta,2014). The low soil organic in the study area (Table 1) due to the texture of the sand-dominated ground so there are many macro pores that would encourage oxidation of organic matter into the soil minerals. The soil organic-C content of paddy field and dryland soil tends to be higher than community forest soil (Table 1). Flooded paddy field causes 
inhibited weathering of soil organic matter, while aerobic atmosphere of dryland increasing weathering of soil organic matter (Tangketasik et al., 2012).

The community forest soil acidity is quite high (Table 1) due to the decomposition of organic matter such as plant litter rudimentary and lead content of organic-C lower than that of other agricultural land. Decomposition influenced microbial activity that utilizes carbon compounds for cell division and the release of $\mathrm{CO}_{2}$, so the soil organic-C is reduced (Jacob 1992 cit Dahlan et al., 2008). Variations in land use and farming systems affect crops are grown in Mojogedang. Farmers in Mojogedang has implemented a system of organic farming but still there are farmers who apply inorganic pesticides to prevent the pest and leaving residue on the farm.

\subsection{Organophosphate Residue Concentration in Research Area}

Pesticide residues are certain substances contained/lagging due directly or indirectly from the application of pesticides (National Standardization Agency 2008). Based on the results of surveys and interviews of farmers in Pereng, Pendem, Gentungan village inorganic pesticides is widely used organophosphate. Organophosphates are phosphoric acid esters are persistent in the environment and has a structure $\equiv \mathrm{P}=\mathrm{O},-\mathrm{PO}$, and group $\equiv \mathrm{P}=\mathrm{S}$ (Elersek and Filipic 2011; Sudarko et al., 2007). Pesticides with high persistency is a pesticide that has a long durability in the soil (Sinulingga, 2006). Organophosphate residues negatively affect soil fertility due to the active ingredient contained so we need a residue analysis.

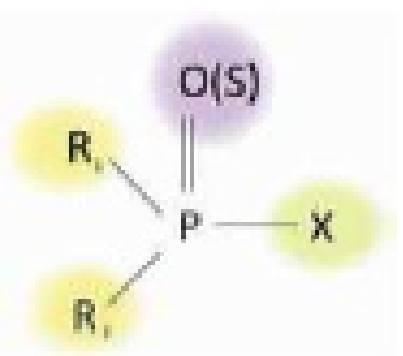

Figure 2. The general structureof organophosphate (Hreljac and Filipič 2009 cit Eleršek and Filipič 2011).

Organophosphate residues were detected in different land use systems include the active ingredient diazinon, chlorpyrifos, profenofos, malathion and ethion operation which includes non-systemic active ingredient (Pandey et al., 2014). Profenofos concentration in horticultural dryland is high (Table 2) more than MRL, while diazinon, parathion, malathion, ethion, chlorpyrifos less than MRL.

Table 2. Concentration of organophosphates in horticultural dryland

\begin{tabular}{llcccc}
\hline Land use & $\begin{array}{c}\text { Active } \\
\text { Ingredients }\end{array}$ & $\begin{array}{c}\text { Concentration residue } \\
\text { of organophosphate } \\
(\mathrm{mg} / \mathrm{Kg})\end{array}$ & $\begin{array}{c}\mathrm{LOD}^{*} \\
(\mathrm{mg} / \mathrm{Kg})\end{array}$ & $\begin{array}{c}\mathrm{MRL}^{* *} \\
(\mathrm{mg} / \mathrm{Kg})\end{array}$ & Remarks \\
\hline \multirow{6}{*}{ Horticultural } & Profenofos & $<9,60 \times 10^{-3}$ & $9,60 \times 10^{-3}$ & & $<\mathrm{MRL}$ \\
dryland & Klorpirifos & $<0,83 \times 10^{-3}$ & $0,83 \times 10^{-3}$ & & $<\mathrm{MRL}$ \\
& Malathion & $<2,06$ & $1,99 \times 10^{-3}$ & 0,05 & $>\mathrm{MRL}$ \\
& Parathion & $<2,24 \times 10^{-3}$ & $1,24 \times 10^{-3}$ & & $<\mathrm{MRL}$ \\
& Ethion & $<6,89 \times 10^{-3}$ & $2,05 \times 10^{-3}$ & & $<\mathrm{MRL}$ \\
\hline
\end{tabular}

Source: Analysis the Integrated Research and Testing Laboratory UGM use simadzu type gas liquid chromatography GC-2010.

Remarks:*LOD (limit of detection) is the maximum limit of detection of the test resultsan equipment.

**MRL (maksismum residue limit) of pesticides in agricultural land (Harsanti et al. 2012).

Frequency of inorganic pesticide spraying to be one factor in the soil residue concentrations. The high concentration of residual fields due to the frequency of spraying horticulture because the average $3 \mathrm{x} / \mathrm{w}$ week. 
Harsanti et al. (2012) stated that the intensive spraying of the pesticide residues higher because (John et al., 2011) accumulates.

Inorganic pesticides and doses applied also affect the residual concentration in soil (Ramika et al. 2012). The high concentration of profenofos in the horticultural dryland as pesticides Curacron 500EC, Deccis 25EC and 500EC Rumba which is widely used and a highdose of $1.5 \mathrm{ml} / \mathrm{L}$. Profenofos active ingredients include active ingredients that have a long degradation time compared to other active ingredients. Acid dryland soil $\mathrm{pH}$ (Table 1) will slow the rate of degradation of profenofos. Profenofos on soil with high acidity will be degraded between 104-108 days (Environmental Protection Agency 1998) while diazinon, chlorpyrifos, malathion, operation and faster option takes 6-35 days (National Pesticide Information Center 2012, the United States Department of Commerce 2008, Andleeb and Qazi 2014, Sastroutomo 1992, the United States Environmental Protection Agency 1994).

The lack of application of organic fertilizers in the horticultural dryland also lead to high profenofos residues. Land of organic fertilizers in small amounts will slow the degradation of anorganic pesticides. This is consistent with the research of Yohanes et al. (2011), application of compost able to remediate pesticide residues faster due to the degradation of nutrients in the form of organic matter.

The residue concentration of organic paddy field less than MRL (Table 3) because there is no inorganic pesticide application. Farmers minimize outbreaks of pests by applying an organic pesticide and plant-based form of fermented cow urine as well as herbs and spices such as turmeric and ginger.

Application of organic pesticides and selected vegetable growers as harmless to the environment. This is supported by a statement of Hasanuddin et al. (2008) that organic pesticides and botanical pesticides containing bioactive substances with the pungent and bitter aroma are easier to dispersed.

Table 3. Concentration of organophosphates in organic paddy field

\begin{tabular}{llcccc}
\hline Land use & $\begin{array}{c}\text { Active } \\
\text { Ingredients }\end{array}$ & $\begin{array}{c}\text { Concentration residue } \\
\text { of organophosphate } \\
(\mathrm{mg} / \mathrm{Kg})\end{array}$ & $\begin{array}{c}\mathrm{LOD}^{*} \\
(\mathrm{mg} / \mathrm{Kg})\end{array}$ & $\begin{array}{c}\mathrm{MRL} * * \\
(\mathrm{mg} / \mathrm{Kg})\end{array}$ & Remarks \\
\hline \multirow{6}{*}{ Organic } & Diazinon & $<9,60 \times 10^{-3}$ & $9,60 \times 10^{-3}$ & & $<\mathrm{MRL}$ \\
paddy field & Klorpirifos & $<0,83 \times 10^{-3}$ & $0,83 \times 10^{-3}$ & & $<\mathrm{MRL}$ \\
& Profenofos & $<1,99 \times 10^{-3}$ & $1,99 \times 10^{-3}$ & & $<\mathrm{MRL}$ \\
& Malathion & $<1,24 \times 10^{-3}$ & $1,24 \times 10^{-3}$ & 0,05 & $<\mathrm{MRL}$ \\
& Parathion & $<2,05 \times 10^{-3}$ & $2,05 \times 10^{-3}$ & & $<\mathrm{MRL}$ \\
& Ethion & $<6,89 \times 10^{-3}$ & $6,89 \times 10^{-3}$ & & $<\mathrm{MRL}$ \\
\hline
\end{tabular}

Source: Analysis of the Integrated Research and Testing Laboratory UGM.

Table 4. Concentration of organophosphates in community forest

\begin{tabular}{llclll}
\hline Land use & $\begin{array}{c}\text { Active } \\
\text { Ingredients }\end{array}$ & $\begin{array}{c}\text { Concentration residue } \\
\text { of organophosphate } \\
(\mathrm{mg} / \mathrm{Kg})\end{array}$ & $\begin{array}{c}\mathrm{LOD}^{*} \\
(\mathrm{mg} / \mathrm{Kg})\end{array}$ & $\begin{array}{c}\text { MRL** } \\
(\mathrm{mg} / \mathrm{Kg})\end{array}$ & Remarks \\
\hline \multirow{6}{*}{ Community } & Diazinon & $<9,60 \times 10^{-3}$ & $9,60 \times 10^{-3}$ & & $<\mathrm{MRL}$ \\
forest & Plorpirifos & $<0,83 \times 10^{-3}$ & $0,83 \times 10^{-3}$ & & $<\mathrm{MRL}$ \\
& Malathion & $<1,99 \times 10^{-3}$ & $1,99 \times 10^{-3}$ & 0,05 & $<\mathrm{MRL}$ \\
& Parathion & $<1,24 \times 10^{-3}$ & $1,24 \times 10^{-3}$ & & $<\mathrm{MRL}$ \\
& Ethion & $<2,05 \times 10^{-3}$ & $2,05 \times 10^{-3}$ & & $<\mathrm{MRL}$ \\
\hline
\end{tabular}

Source: Analysis of the Integrated Research and Testing Laboratory UGM.

The same results are shown in the community forest soil residue concentrations less than MRL. The main results are exploited from community forests is timber so that only the optimized application of fertilizers and no pesticides inorganic applications. The concentration of active ingredient organophosphate residues all inorganic paddy field (Table 4) and dryland (Table 5) less than MRL though there are applications of inorganic pesticides in cultivation. 
Non-intensive spraying of inorganic pesticides in inorganic paddy field as well as the application of organic pesticides by farmers led to low organophosphate residues. The average of inorganic pesticide spraying of inorganic paddy field is $1 \mathrm{x} /$ week and dryland is $3 \mathrm{x} / 3$ months. The low concentration of organophosphates in inorganic paddy fileld and dryland also due to the application of chemical fertilizers. Ion $\mathrm{H}^{+}$contained in chemical fertilizer substitutes the inorganic pesticides molecul so the adsorption is decreased (Odukkathil and Vasudevan 2013). Continuous flooding desreases organophospate residue concentration because of leaching (Manuaba, 2009; Wu et al., 2011). Residue mobillity increasing due to irigation (Muller et al. 2007) especially on the topsoil (Scholtz and Bidleman 2006) so the residue concentration decreased.

Table 5. Concentration of organophosphates in inorganic paddy field

\begin{tabular}{llclll}
\hline Land use & $\begin{array}{c}\text { Active } \\
\text { Ingredients }\end{array}$ & $\begin{array}{c}\text { Concentration residue } \\
\text { of organophosphate } \\
(\mathrm{mg} / \mathrm{Kg})\end{array}$ & $\begin{array}{c}\mathrm{LOD}^{*} \\
(\mathrm{mg} / \mathrm{Kg})\end{array}$ & $\begin{array}{c}\mathrm{MRL}^{* *} \\
(\mathrm{mg} / \mathrm{Kg})\end{array}$ & Remarks \\
\hline \multirow{6}{*}{ Inorganic } & Diazinon & $<9,60 \times 10^{-3}$ & $9,60 \times 10^{-3}$ & & $<\mathrm{MRL}$ \\
paddy field & Klorpirifos & $<0,83 \times 10^{-3}$ & $0,83 \times 10^{-3}$ & & $<\mathrm{MRL}$ \\
& Profenofos & $<1,99 \times 10^{-3}$ & $1,99 \times 10^{-3}$ & \multirow{2}{*}{0,05} & $<\mathrm{MRL}$ \\
& Malathion & $<1,24 \times 10^{-3}$ & $1,24 \times 10^{-3}$ & & $<\mathrm{MRL}$ \\
& Parathion & $<2,05 \times 10^{-3}$ & $2,05 \times 10^{-3}$ & & $<\mathrm{MRL}$ \\
& Ethion & $<6,89 \times 10^{-3}$ & $6,89 \times 10^{-3}$ & & $<\mathrm{MRL}$ \\
\hline
\end{tabular}

Source: Analysis of the Integrated Research and Testing Laboratory UGM.

Table 6. Concentration of organophosphates in dryland

\begin{tabular}{clcccc}
\hline Land use & $\begin{array}{c}\text { Active } \\
\text { Ingredients }\end{array}$ & $\begin{array}{c}\text { Concentration residue } \\
\text { of organophosphate } \\
(\mathrm{mg} / \mathrm{Kg})\end{array}$ & $\begin{array}{c}\mathrm{LOD} * \\
(\mathrm{mg} / \mathrm{Kg})\end{array}$ & $\begin{array}{c}\mathrm{MRL} * * \\
(\mathrm{mg} / \mathrm{Kg})\end{array}$ & Remarks \\
\hline \multirow{6}{*}{ Dryland } & Diazinon & $<9,60 \times 10^{-3}$ & $9,60 \times 10^{-3}$ & & $<\mathrm{MRL}$ \\
& Klorpirifos & $<0,83 \times 10^{-3}$ & $0,83 \times 10^{-3}$ & & $<\mathrm{MRL}$ \\
& Profenofos & $<1,99 \times 10^{-3}$ & $1,99 \times 10^{-3}$ & 0,05 & $<\mathrm{MRL}$ \\
& Malathion & $<1,24 \times 10^{-3}$ & $1,24 \times 10^{-3}$ & & $<\mathrm{MRL}$ \\
& Parathion & $<2,05 \times 10^{-3}$ & $2,05 \times 10^{-3}$ & & $<\mathrm{MRL}$ \\
& Ethion & $<6,89 \times 10^{-3}$ & $6,89 \times 10^{-3}$ & & $<\mathrm{MRL}$ \\
\hline
\end{tabular}

Source: Analysis of the Integrated Research and Testing Laboratory UGM.

High rainfall in Mojogedang affects the concentration of organophosphate residues. Organophosphate residues will be carried by runoff and infiltration water soluble and into deeper soil layers. Organophosphate residues including one pesticide persistence in the soil long, but shorter in if dissolved in water (Sodiq 2000). High and low concentrations of organophosphate due to adsorption and degradation residues.

Correlation properties of soil with Organophosphatesresidue

Adsorption of pesticides is residues binding of pesticides by soil particles, while the degradation of the pesticide residue decomposition process (Tiryaki \& Temur, 2010). The main process of adsorption and chemical degradation of pesticide residues is affected by soil properties such as soil $\mathrm{pH}$, organic-C, soil texture and total microbial (Đurović et al., 2009; Tabassum et al., 2012; Environmental protection Agency, 1998). Linkage properties of soil with concentrations of organophosphate residues can be identified by correlation analysis.

Based on correlation analysis, organophosphate residues negatively correlated with soil texture sand fractions $(\mathrm{r}=-0.601)$, dust fraction $(\mathrm{r}=-0.658)$, clay fraction $(\mathrm{r}=-0.509)$. Soil texture affects the sorption of organophosphate residues. Soil with high clay slow degradation due to residues bound by soil particles (Vischetti, 2009). Location research textured loamy sand (Table 1) is dominated sand fraction so that the inorganic paddy field and dryland organophosphate residues. This is supported by statements Tiryaki and Temur (2010) that the sand fraction may accelerate due to volatilization of organophosphate residues (Đurović et al., 2009) was not able to bind strongly polar residues.

Organophosphate residues positively correlated with organic-C $(\mathrm{r}=0.404)$. Adsorption of organophosphate residues affected by soil organic-C. Low content of organic-C in the study area (Table 1) so that the adsorption rate is also lower pesticide residues. This is supported by Đurović et al. (2009) which states that the rate of adsorption of low pesticide if the content of soil organic-C $5 \%$ due to the high organic-C can increase the soil 
temperature (Tabassum et al., 2012). Singh and Cameotra (2013) adds, high soil temperatures increase evaporation due to increased solubility of pesticide residues in soil (Aktar et al., 2009).

Organophosphate residues positively correlated with soil $\mathrm{pH}(\mathrm{r}=0.165)$. Soil $\mathrm{pH}$ stability associated with organophosphate residues. Acidity of soil in the study (Table 1) reducing degradation by hydrolysis of organophosphate residues (Hero et al., 2007). Odukkathil and Vasudevan (2013) add that soil acidity change pesticide becomes negatively charged or positively charged zero, so the land is negatively charged, it will positively charged pesticideadsorbed.

Total microbia describes microbia activity that plays a role in the process of adsorption (Okpokwasili and Nweke, 2005) and biodegradation of hazardous chemical compounds including organophosphate residues (Muñoz et al. 2012, Oleszczuk et al. 2014). Organophosphate residues were positively correlated $(r=0.447)$ worth a total of microbes. The high concentration of organophosphate residues will increase soil microbia activity. Pesticide residues are used as energy by microbia through degradation. Microbes produce organophosphorus hydrolase enzymes to break the C and P (Singh \& Walker, 2006). Termination bond organophosphorus compounds during degradation used by microbes as a source of carbon and phosphate (Jacob et al., 1987; Yohanes et al., 2011).

\subsection{Distribution of Residual Organophosphate Location Research}

There are two criteria organophosphate residues in the study area is the land with low residual concentrations less than MRL and land with high residual concentrations more than MRL (Harsanti et al., 2012). Based on these criteria in the Pereng, Pendem, and Gentungan Village of organophosphate residues distribution is low. Organophosphate residues more than MRL dominated dryland, while the organophosphate residues less than MRL dominated paddy fields and community forest.

Many farmers have switched to organic farming systems or semi-organic paddy fields even though there were applied organophosphate pesticide residues anorganic so low. Inorganic pesticides were applied and the frequency of spraying that considering the level of pest attacks affect the accumulation of residue (Yuantari 2011). Organophosphate residues of dryland more than MRL is influenced by crop plants such as horticultural farmers and dryland. Horticulture cultivation in dryland particular had high pest attacks, so that farmers prefer to use inorganic pesticides because it has eradicated the pest faster than the organic pesticides.

Distribution of low organophosphate residues influenced the nature of the soil in the study area. Soil studies included orders Entisols with loamy sand texture, acid, low organic-C effect on the degradation of organophosphate residues in the soil. Site conditions with high rainfall resulting organophosphate residues undergo surface runoff, thus washed and hydrolyzed (Munawar 2011). Distribution of organophosphate residues in Pereng, Pendem, Gentungan Village distribution maps presented in organophosphate residues.

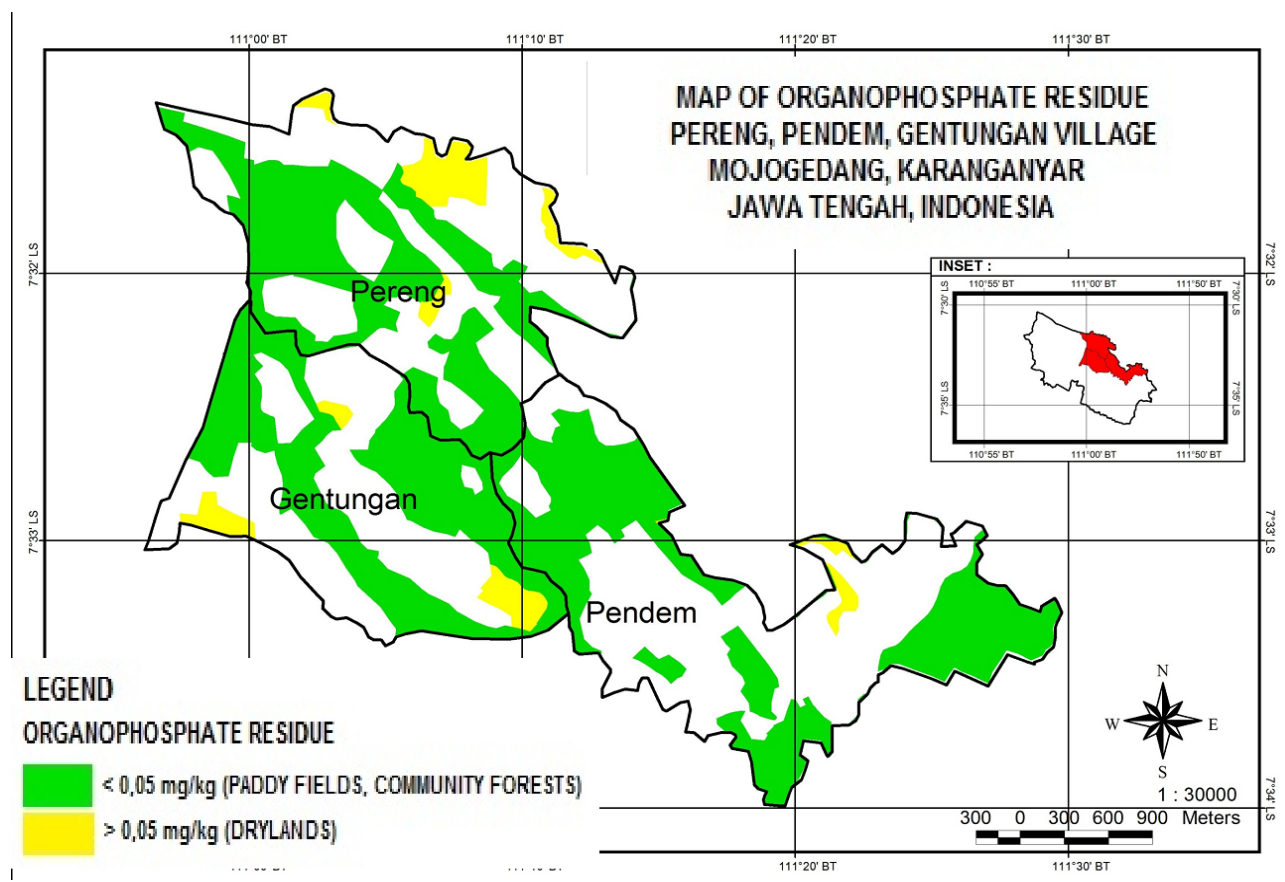

Figure 3. Map of distribition organophosphate residue 


\section{Conclusions}

Organophosphate residues in organic paddy field, inorganic paddy field, dryland, and community forest less than MRL $(0.05 \mathrm{mg} / \mathrm{kg})$. Residue levels of horticultural dryland with profenofos active ingredient more than MRL $(62,060 \mathrm{mg} / \mathrm{Kg})$. Soil properties correlated with organophosphate residues are soil texture, organic-C, $\mathrm{pH}$, total microbia.

Advice can be given that there is a need for further research to determine organophosphate residues in agricultural produce and study other types of inorganic pesticide residues in agricultural land of Mojogedang.

\section{Acknowledgments}

The financial support of this study was provided by Sebelas Maret University. The authors would sincerely like to dedicate this paper to dr. Setyo Sri Rahardjo, M.Kes, whose help was crucial in suggestion, accommodations and thanks to Mrs. Paiman, Mrs. Sutiman for guidance. Reviewers are sincerely commended for their contribution to improve the manuscript.

\section{References}

Aktar, W., Sengupta, D., \& Chowdhury, A. (2009). Impact of pesticides use in agriculture: Their benefits and hazards. Interdisc Toxicol, 2(1), 1-12. http://dx.doi.org/10.2478/v10102-009-0001-7

Andleeb, S., \&Qazi, J. I. (2014). Assessment of detoxification of malathion by Pseudomonas isolates. $J$ Microbiology Research, 8(11), 1170-1177.

Arifin, Z. (2011). Analysis of the quality index value Ultisols in different land use. Agroteksos, 21(1), 47-54.

Bai, Y., Chen, J., Yang, Y., Guo, L., \&Zhang, C. (2010). Degradation of organophosphorus pesticide induced by oxygen plasma: effects of operating parameters and reaction mechanisms. Chemosphere, 81(3), 408-414. http://dx.doi.org/10.1016/j.chemosphere.2010.06.071

Bhupander, K. (2011). Residues of pesticides and herbicides in soils from agriculture areas of delhi region, India. $J$ Environment Earth Science, 1(2), 1-9.

Chowdhary, S., Bhattacharyya, R., \& Banerjee, D. (2014). Clinica chimica acta acute organophosphorus poisoning. Clinica Chimica Acta,431, 66-76. http://dx.doi.org/10.1016/j.cca.2014.01.024

Dahlan, M., Mulyati, \& Dulur, N. W. D. (2008). Study of organic and inorganic fertilizer application on changes of some soil properties entisol. Agroteksos, 18(1-3), 20-26.

Directorate of Fertilizers and Pesticides. (2012). Pesticide policy in Indonesia. Bogor.

Djunaedy, A. (2009). Biopesticide governing organism as an environmentally friendly plant bully. Embryo, 6(1), 88-95.

Đurović, R., Umiljendić, J. G., \& Đorđević, T. (2009). Effects of organic matter and clay content in soil on pesticide adsorption processes. J Pestic. Phytomed, 24, 51-57. http://dx.doi.org/10.2298/PIF0901051D

Eleršek, T., \& Filipič, M. (2011). Pestticides-The Impacts of Pesticides Exposure:Organophosphorus Pesticides-Mechanisms of Their Toxicity. Intech.

Enviromental Protection Agency. (1994). Environmental Risk Assessment for Ethion. Retrieved from http://www.epa.gov

Enviromental Protection Agency. (1998). Environmental Risk Assessment for Profenofos. Retrieved from http://www.epa.gov

Fatimah, I., \& Nugraha, J. (2007). Quantitative analysis of the relationship of structure and solubility of the active compounds of pesticide organofosfat: linear model approach and cluster method. J Ilmu Dasar, 8(1), 91-102.

Harsanti, E. S., Martono, E., Sudarmadji, \& Sudibyakto, H. A. (2012). Insecticides residue in soils and profenofos products Allium ascalonicum shallots, 1. at Center of onions in Bantul. J Lingkungan Tropis, 6(2), 131-138.

Hasan, A. (2006). The impact of use of organochlorin. J Teknik Lingkungan, 7(1), 90-96.

Hasanuddin, H., \& Dahlan, F. (2008). The application of pesticides on vegetable pertanaman corn. J Agrisistem, $4(1), 11-18$.

Hiera, L., Santana, H., \& Thais, A. (2007). Adsorption of glyphosate on clays and soils from parana state: effect of $\mathrm{pH}$ and competitive adsorption of phosphate. Brazilian Archives Biology Technology, 50, 385-394. 
Indratin, Poniman, \& Ardiwinata, A. N. (2010). Organofosfat residue in soil on some Rice production center in West Java . Environmental Studies Hall Farm. Pati.

Jacob, G. S., Garbow, J. R., Scharfer, J., \& Kishore, G. M. (1987). Solid-state nmr studies of regulation of n-(phosphonomethy1) glycine and glycine metabolism in Pseudomonas sp. strain PG2982. J Biological Chemistry, 262(4), 1552-1557.

Leroy, M. T. et al. (2010). Application of laccase-mediator system (LMS) for the degradation of organophosphorus compounds. Chemico-Biological 393-396.http://dx.doi.org/10.1016/j.cbi.2010.02.001

Manuaba, Putra, I. B. (2009). Carbamate pesticides in water impurities Lake Buyan Buleleng of Bali. J Kimia, $3(1), 47-54$.

Maroeto, Sasongko, P. E. (2004). Selection of alternative food crops on a coastal land evaluation approach the level of conformity with land use in the area of Sidoarjo. J Ilmu-ilmu Pertanian, 4(1), 30-40.

Muller, K., Magesan, G. N., \&Bolan, N. S. (2007). A critical review of the influence of effluent irrigation on the fate of pesticides in soil. $J$ Agriculture, Ecosystems, Environment, 129, 93-116 (Abstr). http://dx.doi.org/10.1016/j.agee.2006.08.016

Munawar, Ali. (2011). Soil fertility and Plant Nutrition. IPB Press. Bogor.

Munir, Moch. (1996). Main lands in Indonesia. Dunia Pustaka Jaya. Jakarta.

Muñoz-Leoz, B., Garbisu, C., Antigüedad, I., \& Ruiz-Romera, E. (2012). fertilization can modify the non-target effects of pesticides on soil microbial communities. Soil Biology Biochemistry, 48, 125-134. http://dx.doi.org/10.1016/j.soilbio.2012.01.021

National Pesticide Information Center. (2012). Diazinon. Retrieved from http://npic.orst.edu/ingred/diazinon.html

National Stardadisasi Agency. (2008). Maximum limits of pesticide residues on agricultural. Retrieved from http://ditjenbun.pertanian.go.id.

Noordwijk, M. V., \& Hairiah, K. (2006). Intensification of agriculture, soil biodiversity and agro-ecosystem function. Agrivita, 28(3).

Nurlamba, N. S., Zackiyah, \& Siswaningsih, W. (2010). Study of the kinetic interaction of Chitosan-bentonite and its adsorption diazinon to kitpsan-bentonite. J Sains dan Teknologi Kimia, 1(2), 159-169.

Odukkathil, G., \& Vasudevan, N. (2013). Toxicity and bioremediation of pesticides in agricultural soil. Environmental Science Biotechnology, 12, 421-444. http://dx.doi.org/10.1007/s11157-013-9320-4

Okpokwasili, G. C., \& Nweke, C. O. (2005). Microbial growth and substrate utilization kinetics. African J Biotechnology, 5(4), 305-317.

Oleszczuk, P. et al. (2014). Effect Of pesticides on microorganisms, enzymatic activity and plant in biochar-amended soil. Geoderma, 214-215, 10-18. http://dx.doi.org/10.1016/j.geoderma.2013.10.010

Pandey, A. P. et al. (2014). A novel and sensitive kinetic method for the determination of malathion using chromogenic reagent. J Microchemical, 113, 83-89. http://dx.doi.org/10.1016/j.microc.2013.11.005

Raini, Mariana. (2007). Toxicology of pesticides and pesticide poisoning caused by handling. Media Litbang Kesehatan, 17(3), 10-17.

Ramika, R., Safni, \& Lukman, U. (2012). Degradation of profenofos compounds in insecticides curacron 500EC in photolysis with addition of TiO2-zeolite. J Kimia Unand, 1(1), 92-98.

Rustia, H.N., Wispriyono, B., Susanna, D., \& Luthfiah, F.N. (2010). Long exposure organofosfat to decrease enzyme activity in blood of farmers kolinesterase vegetables. Makara Kesehatan, 14(2), 95-101.

Sastroutomo, S. S. (1992). Pesticides, basics and Impact Mitigation. Jakarta: PT. GramediaPustaka Utama.

Scholtz, M. T., \& Bidleman, T. F. (2006). Modelling of the long term fate of pesticide residues in agriculture soils and their surface exchange with the atmosphere: part I. model description and evaluation. J Sci. Total Environ, 368 (2-3), 823-838 (Abstr). http://dx.doi.org/10.1016/j.scitotenv.2006.03.023

Sevindrajuta. (2014). The effect of Giving Some Measure of Cow Manure to chemical properties of Inceptisol and plant growth Amaranthus tricolor, L). Faculty Of Agriculture Muhammadiyah Sumatera Barat University. 
Singh, A. K., \& Cameotra, S. S. (2013). Adsorption and desorption behavior of chlorotriazine herbicides in the agricultural soils. J Petroleum Environmental, 4(5), 1-6.http://dx.doi.org/10.4172/2157-7463.1000154

Singh, B. K., \& Walker, A. (2006). Microbial degradation of organophosphorus compunds. FEMS Microbiol Rev., 30, 428-471.http://dx.doi.org/10.1111/j.1574-6976.2006.00018.x

Sinulingga, K. (2006). Study on organoklor residues of carrot Daucus carota l. in the Karo district, Sumatera Utara. S Sistem Teknik Industri, 7(1), 92-97.

Sodiq, M. (2000). Effect of pesticides on soil organisms life. Mapeta, 2(5), 20-22.

Statistic Indonesia. (2014). Population Growth. Retrieved from http://www.datastatistik-indonesia.com/portal/index.php?option=com_content\&task=view\&id=919

Statistic of Karanganyar. (2013). Mojogedang in 2013. Retrieved from http://karanganyarkab.bps.go.id.

Sudarko, Suwardiyanto, D., \& Ratnadewi, I. (2007). Modifications in combination with acetylcholinesterase in silico biosensor for organophosphate. J Kimia Indonesia, 2(1), 1-6.

Sudarmo, S. (1991). Pesticide. Kanisius. Yogyakarta.

Sularti, Muhlisin, A. (2011). The level knowledge of the dangers pesticides and habit of Wearing Protective Equipment Themselves as seen from the emergence of Signs symptoms of Poisoning on a group of farmers in Karanganyar. Faculty Of Medicine, Muhammadiyah Surakarta University.

Tabassum, N., Rafique, U., \&Munir, N. (2012). Application of adsorption process for remediation of organophosphate insecticides: A biochemical approach. J Chemical Environmental Engineering, 3(6), 381-385.

Tangketasik, A., Wikarniti, N. M., Soniari, N. N., \& Narka, I. W. (2012). Levels of soil organic matter in soils of paddy fields and moorland in Bali and its relationship with soil texture .Agrotrop, 2(2), 101-107.

Utami, S. N. H., \& Handayani, S. (2003). Chemical properties of organic farming systems in Entisol. J Ilmu Pertanian, 10(2), 63-69.

Vischetti, C. et al. (2009). Pesticides adsorption and degradation in fine earth and rock fragments of two soils of different origin. Geoderma, 154, 348-352. http://dx.doi.org/10.1016/j.geoderma.2009.11.006

$\mathrm{Wu}, \mathrm{X}$. M. et al. (2011). Prediction of bioavailability of chlorpyrifos residues in soil to earthworms. $J$ Soil Science Plant Nutrition, 11(1), 44-57. http://dx.doi.org/10.4067/S0718-95162011000100004

Yohanes, S., Utama, M. S., Tika, W., \& Gunadnya, I. B. P. (2011). Optimization of process of bioremediation for pesticide-polluted land in Situpada group mankoze. J Teknik Industri, 12(1), 51-56.

Yuantari, Catur. (2011). The impact of Organochlorin Pesticides on human health and environment and mitigation. Proceedings of The National Seminar. Faculty of Health, University Of Dian Nuswantoro Semarang.

\section{Copyrights}

Copyright for this article is retained by the author(s), with first publication rights granted to the journal.

This is an open-access article distributed under the terms and conditions of the Creative Commons Attribution license (http://creativecommons.org/licenses/by/3.0/). 